Light, Duncan, and Craig Young. "Habit, memory, and the persistence of socialist-era street names in postsocialist Bucharest, Romania." Annals of the Association of American Geographers 104.3 (2014): 668-685.

\title{
Habit, memory, and the persistence of socialist-era street names in post-socialist Bucharest, Romania.
}

\author{
Duncan Light \\ Division of Geography and Environmental Management, \\ School of Science and the Environment, \\ Manchester Metropolitan University, \\ John Dalton Building, \\ Chester Street, \\ Manchester, \\ M1 5GD, \\ UK, \\ emaild.light@mmu.ac.uk \\ Craig Young \\ Division of Geography and Environmental Management, \\ School of Science and the Environment, \\ Manchester Metropolitan University, \\ John Dalton Building, \\ Chester Street, \\ Manchester, \\ M1 5GD, \\ UK, \\ emaild.light@mmu.ac.uk \\ Phone: +44 1612476198
}




\title{
Habit, memory, and the persistence of socialist-era street names in post-socialist Bucharest, Romania.
}

\begin{abstract}
:
The critical study of toponymy has paid considerable attention to the renaming of urban places following revolutionary political change. Such renaming is intended to institutionalize a new political agenda through shaping the meanings in everyday practices and landscapes. Renaming, however, may not always be successful and this article examines this issue with reference to a market in Bucharest, Romania. Originally named Piaţa Moghioroş during the socialist era to commemorate a leading Communist Party activist, the market was renamed in the post-socialist period. Yet, more than two decades on, the original name remains in widespread everyday use. Using a mixed-method approach we seek to advance the critical toponymies literature by exploring the persistence of the socialist-era name within everyday practice. Although many authors have highlighted the issue of popular resistance to an unpopular renaming we find little evidence of conscious resistance, and instead we explore the importance of habit within everyday practices as an explanation, drawing on an understanding of habit derived from socio-cognitive psychology. This perspective proposes that habits are stable and hard to break if the broader context in which they are situated is stable and we suggest that this explanation, rather than popular contestation, has more to offer in understanding the persistence of the toponym Piaţa Moghioroş. We thus highlight the importance of considering how the "users" of place names react to the changes of such names and create their own meanings in relation to them in ways unintended by elites.
\end{abstract}

Key words: critical toponymies; everyday life; habit; memory; Romania. 


\section{Habit, memory, and the persistence of socialist-era street names in post-socialist Bucharest, Romania.}

In the Drumul Taberei district of Bucharest, the capital of Romania, there is a market on a major intersection (see Figures 1 and 2). In the central market hall are rows of concrete tables where farmers from the surrounding agricultural districts sell fresh vegetables. In the sprawling area around the central hall a range of stalls and kiosks sell cheap consumer goods and clothing. The market is used mainly by those on lower incomes since Bucharest's rapidly expanding middle class shops at the recently established European hypermarkets or the exclusive shops in the city's malls. There is nothing particularly noteworthy about this market except its name. Originally it was named Piaţa Moghioroș (Moghioroș Market) after Alexandru Moghioroș (1911-1969), a senior member of the Romanian Communist Party. After his death the market and the adjacent boulevard (Strada Moghioroş) were named in his honor, and a small statue was erected on the boulevard. During the post-socialist period the Bucharest Primărie (City Hall) renamed both places that commemorated Moghioroş as part of a wider renaming of the urban landscape (Light 2004). Thus, the boulevard became Strada Braşov (after a city which experienced heavy fighting during the 1989 revolution). The market was renamed Piaţa Drumul Taberei after the name of the local district (whose name means The Road of the Camp and refers to an army camp established by an $18^{\text {th }}$ century military figure).

FIGURES 1 and 2 AFTER HERE

Yet, more than twenty years after the fall of socialism, many people in Drumul Taberei still call the market by its socialist-era name, Piaţa Moghioroș. Moreover, it is not just older people who do this since the name has also been widely adopted by a younger generation born after 1989. Indeed, the name Moghioroș is becoming more widely used to refer to an area of the city which is larger than the market itself, even though officially the name no longer exists. This persistence of a socialist-era place name sits uneasily with recent academic analyses which emphasize the significance of renaming places after a period of revolutionary 
political change. In this article we explore the survival of this socialist toponym in the mundane life of the post-socialist city and examine what it tells us about both official, topdown practices of (re-)naming places, and everyday responses to such practices.

\section{Naming and Renaming Urban Places}

Over the past decade political and cultural geographers have paid considerable attention to the relationships between urban space, political power, and public memory. This has led to a renewed interest in place names (and naming practices) and the emergence of an approach known as "critical toponymies" (Berg and Vuolteenaho 2009). This treats the attribution of names to places, streets, and buildings as more than a merely administrative procedure. It also rejects the atheoretical, descriptive, and often encyclopedic approach of many earlier studies of place names (Kearns and Berg 2002; Vuolteenaho and Berg 2009). Instead, critical toponymy treats place naming as "a socially embedded act, one that involves power relations" (Vuolteenaho and Berg 2009, 9). The very decision to allocate a name - and the name itself can be considered as a performative act that is central to the social production of place (RoseRedwood 2008).

At one level, the act of attributing names to streets and buildings produces the coherent and ordered urban space required by modern governmentality (Rose-Redwood 2008; RoseRedwood, Alderman, and Azaryahu 2010). At another level, the decisions about the names attributed to places, streets, and buildings are embedded in broader structures of power and authority. Such names are not accidental, or politically innocent. Instead, certain names are chosen and foregrounded as appropriate or acceptable, a decision almost always taken by political elites. Naming places is, therefore, a way of inscribing a particular worldview and set of political values onto the landscape. Azaryahu $(1996,312)$ argues that urban place names are "instrumental in substantiating the ruling socio-political order and its particular "theory of the world' in the cityscape". Place names, along with statues, monuments, memorials, monumental buildings, and ceremonial spaces, are a key means through which urban space is signified and saturated with political values (Verdery 1999).

Naming places is also central to the cultural production of collective memory. Place names are one means through which an authorized narrative of history is reified in the built 
environment (Azaryahu 1996). Many urban place names are overtly commemorative and honor key events and personalities from the past. Such names "introduce an authorized version of history into the ordinary settings of everyday life" (Azaryahu 1996, 312; see also Azaryahu 2009). They may be invoked in all sorts of mundane contexts such as addresses, maps, road signs, or directions given to strangers (Alderman 2002). The performative act of reciting place names (Kearns and Berg 2002; Rose-Redwood 2008) contributes to the ongoing reproduction of official history and collective memory within everyday life and spaces.

Urban place names are, however, politically and culturally contingent. They are produced for particular purposes in particular contexts. This makes them vulnerable to political change (Azaryahu 1996, 1997, 2009). In particular, critical moments of radical or revolutionary change are accompanied by efforts to redefine national history and national identity which, in turn, entails a reconfiguring of public memory (Forest and Johnson 2002). In these circumstances the symbolic landscape of the former regime is subject to a process of "landscape cleansing" (Czepczyński 2009) which includes the familiar rituals of pulling down statues or destroying monuments. The renaming of urban streets and buildings is central to this process. As Azaryahu (1996, 318) argues: "Through renamings, the new regime proclaims the beginning of a new era while demonstrating both its resoluteness and its selfconfidence". This reconfiguring of urban toponymy is underpinned by simultaneous processes of decommemoration (removing the inappropriate toponymy inherited from the former regime) and commemoration of different personalities and events that accord with the new authorized narrative of national history and identity (Azaryahu 1996, 1997). Such "toponymic cleansing" (Rose-Redwood, Alderman, and Azaryahu 2010, 460) is relatively quick and cheap, and is assumed by elites to have an immediate impact as new place names are introduced into the language, practices, and landscapes of everyday life (Azaryahu 1996).

Elite-led projects to reconfigure the toponymic landscape following radical political change have received considerable academic scrutiny in recent years. Much less attention has focused on the reception of street name changes by the populations affected by them. While elites may decree that urban place names should change, the new names may not find immediate or universal acceptance (Azaryahu 2012). Instead, newly imposed names can be the focus of disagreement, dispute, and contestation. For example, following the collapse of the socialist German Democratic Republic in 1989, a commission appointed by the Berlin Senate proposed street name changes in the Mitte district (formerly East Berlin). These were intended 
to decommemorate the socialist era and introduce new names drawn from Germany's preWorld War II democratic tradition. Yet the plans were strongly contested by local residents who campaigned for the retention of the former names (De Soto 1996). Similarly the renaming of Sixth Avenue in New York as Avenue of the Americas in 1945 attracted little popular support and, more than sixty years later, most New Yorkers still refer to it as Sixth Avenue (Rose-Redwood 2008).

This issue of contestation or resistance to officially-endorsed place names is a prominent theme within critical toponymic studies. Azaryahu $(1996,315)$ argues that "the rejection of names by a population, or segments of it, is a profound act of resistance". It is a way of challenging dominant ideologies and constructions of history through commonplace practices that are embedded in everyday life (Rose-Redwood, Alderman, and Azaryahu 2010). Such resistance takes various forms (Azaryahu 1996; Kearns and Berg 2002; Vuolteenaho and Berg 2009; Rose-Redwood, Alderman, and Azaryahu 2010). One response is a refusal to use an officially imposed name. As Kearns and Berg (2002) and Rose-Redwood (2008) argue, official toponyms lose much of their performative impact if they are not spoken. Hence resistance is often expressed through the adoption of an alternative or parallel set of place names. For example, Yeoh (1992) examines how the colonial authorities in Singapore allocated street names that were predominantly commemorative in character and underpinned by European conceptions of landscape. These were, however, largely ignored by the nonEuropean inhabitants who developed their own street names (derived from local landmarks or communities) which circulated in parallel. Another response is unauthorized namings which may demonstratively defy the dominant order (Azaryahu 1996). These include defacing or painting over official street name signs or painting alternative names onto walls and buildings. A further response is grass-roots campaigns lobbying for an officially-approved change of name (see Alderman (2002) on the case of streets named after Martin Luther King). Finally, the way of pronouncing place names within everyday speech can be a deliberate act of resistance (Kearns and Berg 2002).

Resistance to top-down naming practices is an important practice, but it does not explain every instance where place names fail to find popular acceptance. Instead, in this article we argue that responses to place names may be much less purposeful and, instead, may be characterized more by habit or inertia. In doing so we link critical toponymic studies to recent trends in geography and related disciplines which seek to understand the everyday through 
multiple lenses, and not just the lens of resistance (Harrison 2000; Highmore 2004, 2011; Moran 2005; Scott 2009; Edensor 2010). In particular, we follow Azaryahu's call to be open to issues of "ostensible incoherence, polysemy and heterogeneity" (2011, 30) when considering street names. We argue for a consideration of reactions to place names that go beyond deliberate resistance, and which are rooted in more ambivalent and personal emotional geographies. This links to a notable imbalance within critical toponymic studies which has focused extensively on elite practices of naming and renaming, but has rather neglected the commonplace, banal, and everyday relationships with place names of residents of the city. Yet, as Azaryahu (2011) argues, we need to pay more attention to the users of urban toponyms as co-creators of meaning. Thus, we analyze how residents in the Drumul Taberei district use the name of the market in their everyday lives and how this relates to the surprising persistence of a socialist-era toponym.

\section{Exploring the Persistence of the Toponym Piaţa Moghioroş}

To explore the contemporary usage of the parallel toponyms Piaţa Moghioroş and Piaţa Drumul Taberei we employed a mixed-method approach with three principal sources of data. The first was a form of (covert) participant observation. One of the authors spent 2004 living in Drumul Taberei and visited the market regularly to purchase food (he has spent at least a week in the district each year since). Having a prior interest in place names, and being a Romanian speaker, he quickly became aware when talking to neighbors and acquaintances that a socialist-era name for the market was in widespread everyday use. Therefore, while resident in Drumul Taberei, he made a record of the ways that local people spoke about the market in their everyday lives and the names that they used for it, along with details of their backgrounds. As Kearns (2005) argues, observation, used in this way, can add value to interpreting the experience of place. This rich (if informal) data both informed the subsequent questionnaire design (in terms of the questions asked and the issues covered) and complemented the interpretation of the data gathered by more formal methods.

Second, we surveyed users of the market to explore awareness and use of the market's current and former names. The questionnaire comprised 11 questions (both closed and open-ended) plus demographic questions. Native Romanian speakers administered the survey in the market itself. A systematic sampling strategy was adopted whereby every fifth adult to walk past the 
interviewer was asked to participate $(n=169)$. The sample comprises a balanced representation of each age group and gender (although perhaps with an over-representation of the 21-30 classification - see Table 1). The majority of the market's users have lived in Bucharest for twenty years or more. Despite the lack of any systematic data regarding the composition of the market's clientele, we are confident that this sample is representative of them, based on our own experiences of the market. In the analysis that follows relationships between variables are explored using the two-sample chi-square test (although only relationships that are statistically significant are reported). Open-ended questions were analyzed using both content analysis (to identify the responses which occurred most frequently) and discourse analysis (to identify dominant but also counter-discourses in the everyday use of toponyms). Third, a number of field visits were undertaken in and around the market to analyze street signage and other uses of the different toponyms.

\section{TABLE 1 AFTER HERE}

Following Romania's December 1989 "revolution" the socialist past was quickly repudiated as the country sought a new course of political and economic development. In the context of broader elite projects to redefine collective memory, monuments and place names which commemorated the socialist past were disavowed and efforts made to eradicate them from the landscape of the capital (see Forest and Johnson 2002). Thus, street name signs for Strada Moghioroș were removed whilst new ones for Strada Braşov were erected. Similarly, new signage was introduced to the market identifying it as Piaţa Drumul Taberei (see Figure 3). Despite these changes our survey indicates that the majority of respondents (57 percent) continue to use the socialist-era name (Piaţa Moghioroş) for the market. Fewer people (40 percent) use the official post-1990 name of Piaţa Drumul Taberei. A handful of people (three percent) used Piaţa Sergiu Celibidache, the name attributed to the nearby traffic intersection after 1989 where there is a small monument to the Romanian conductor.

\section{FIGURE 3 AFTER HERE}

The age of respondents might be expected to influence the name used for the market (with, for example, younger people being more likely to use the official name) but this relationship was not statistically significant. Instead, younger people are no more likely to use Piaţa Drumul Taberei and indeed 70 percent of those aged under 30 used the name Piaţa 
Moghioroş. This indicates how a generation born after 1989 has adopted the former name. Similarly, older people are not more likely to use Piaţa Moghioroş, suggesting that its continued use is not simply the result of opposition to renaming among older people. Similarly, no relationship was apparent between name used and length of residence in Bucharest. Those who have resided longer in the capital (and have therefore witnessed the market's renaming) are no more likely to use the old or the new name.

It is clear that, although the market has been formally renamed, the socialist-era name remains in widespread everyday use. Indeed, two parallel names for the market are in circulation. The next stage of the analysis explores why people continue to use the old name and their views about it. A first step is to analyze people's knowledge of Alexandru Moghioroş and his role in Romanian history. Although the majority of people questioned continue to call the market Moghioroş, most (57 percent) did not know who Moghioroş was. As might be expected this awareness varied significantly by age $\left(X^{2}=49.13, p<0.001\right)$. People in the 21-30 and 31-40 age groups were less likely to have heard of Moghioroş, whereas those aged over 60 were more likely to have done so. Clearly those who are older are more likely to remember Moghioroş's role in the Romanian Communist Party and his death in 1969. Younger people, on the other hand, are unlikely to have encountered Moghioroş through the education system. Even those educated during the last decade of socialism are unlikely to have heard of Moghioroş due to the personality cult constructed around the state president Nicolae Ceauşescu which involved marginalizing other Communist Party activists (Boia 2001). Those who had heard of Alexandru Moghioroş gave a range of opinions about his significance. By far the most common response was "a communist" (followed by similar descriptions such as "a communist leader", "a communist minister", a "member of the Central Committee"). Some, however, mis-identified him as a general, a writer or a leader of Hungary.

No significant relationship was apparent between awareness of Moghioroş and the name used for the market. Contrary to what might be expected, those who had heard of Moghioroş were no more likely to use the name Piaţa Moghioroş than those who had not. Moreover, although older people are more likely to have heard of the activist they are not more likely to use his name for the market. This suggests that the practice of using the name Moghioroş is not part of a purposeful strategy to honor the politician or to resist the official renaming of the market. 
We also explored the reasons for the persistence of the name Moghioroş (Table 2). While the critical toponymies literature assumes that street names are important in carrying meaning, in actual fact not everybody is interested in, or knowledgeable about, the issue. Indeed, matters that might seem of glaring importance to academic researchers may be of little consequence to people going about their everyday lives. Thus, over a quarter of respondents offered no reason for the persistence of the socialist name for the market. On the other hand, almost three-quarters had an opinion and, as Table 2 shows, the most common reason ( 22 percent) was "out of habit". For example, respondents stated: "that's what people have got used to", or "that's what they've learnt it's called". The next most common category was the set of reasons related to Moghioroş as the former name of the market, a name that had been in use for a long period of time. For example, respondents suggested that the continued use of the socialist toponym was "because it's the original name, that's what it was called before", or "for us it is simpler because that's how it was named before." Some respondents related the name to people's embedded memories of the area: "we're talking about a name impregnated in memory over a long time, it's related to the oral character and how the name is transmitted", and "that's how they remember it, or how they learnt it from friends or relatives.”

\section{TABLE 2 AFTER HERE}

A smaller number of respondents attributed the survival of the toponym to nearby elements of the urban landscape also formerly named after Moghioroş. For example, "for tens of years this street was called Moghioroş", "The street here, Strada Braşov, was called Moghioroş before", or "because it's on Moghioroş Street". Such responses suggest that some people continue to use the old street name as a reference point. In fact, everything formerly named in honor of Moghioroş was renamed after 1989 and the nearby park was never officially named after him. A minority of respondents suggested that the persistence of the name was in recognition of Alexandru Moghioroş and his contribution to Romanian history. For example, some respondents suggested the name was still current "because he was an important man, a historic man" and "because he was a minister". The other reasons for the persistence of the place name were given only by very small numbers of respondents.

We next explored views about the continued use of this socialist-era toponym (Table 3). For many people this was not a burning issue and 18 percent did not care or had no opinion on the 
matter. The dominant response of the remaining 82 percent was that the continued use of the name was due to habit, and because people had become accustomed to it before 1989 (rather than a deliberate strategy to preserve the name in everyday usage). For example, one person stated: "It seems normal to me; people called the market that for many years and for them it is very difficult to adapt to the new name." Others stated that "the name can't be changed in peoples' memories", or "the name Moghioroş is deeply rooted", indicating that the name has become embedded within everyday memory and practice in the area. Again this highlights the disparity between the renaming projects of elites and the responses of those directly affected by such changes. As one respondent argued "it's difficult to erase something that is imprinted so well in people's minds."

The second most common response (Table 3) was that, for most people, the name Piaţa Moghioroş had no relationship to communism and had become detached from its referent. One person said: “It doesn't have any relationship with the communists, neither does it seem to me to be important. It's just a name". Another said: "It kept the name over the years, but doesn't have any relationship with the communists". A number of people argued that most users of the market had little knowledge of Alexandru Moghioroş indicating that the name has become detached from the historical figure. One person stated: "Nobody knows who Moghioroş was; what does it matter?". Another argued: "We're talking about a name and that's it. It's empty of sense and contents. Nobody praises Moghioroş”. Similarly: "90 percent of the population don't know that he was a communist".

\section{TABLE 3 AFTER HERE}

Few people seemed concerned that the socialist-era toponym Piaţa Moghioroş remained in daily use and only seven people expressed unease. For example, one said "It disturbs me; however it's difficult for many people to adapt to the new name". Another said "It's not OK but it's out of habit". Only one person called for deliberate action to discourage use of the former name, saying that "the authorities should take measures, namely, to write Piaţa Drumul Taberei in large letters and the branches of the banks should change their names."

Other explanations were given by smaller numbers of people. Just over one in ten respondents considered that the survival of the socialist name was related to nostalgia for the socialist era or an inability to shake off a socialist mentality. As one said, "It was better in the time of the 
communists. I'm pleased that people still call the market that [Moghioroş]". Another said, "in the communist period the world was better". This is a generation that was traumatized by the collapse of the socialist system and Romania, like other countries in the region, witnessed a growth in nostalgia for the socialist era. It would, however, be too simplistic to attribute the persistence of the socialist-era name simply to nostalgia. Previous studies have shown postsocialist nostalgia to be a complex phenomenon (Ekman and Linde 2005; Todorova and Gille 2012). Many older Romanians are unambiguously positive in their memories of the socialist era. For some, the continued use of the name Piaţa Moghioroş may indeed be a small act of resistance against an elite-sponsored renaming which seeks to eradicate reference to the socialist past. Nobody, however, specifically stated that they used the name Moghioroş as a deliberate act of opposition to the renaming of the market. Moreover, only a handful (4.2 percent) felt that Alexandru Moghioroş was a sufficiently important historical figure to merit commemoration. For example, one person said: "It seems that he was an important man. What does it matter what sort of regime he was part of?".

Other respondents attributed the continued use of Piaţa Moghioroş to a broader continuity with the socialist era. Few disagree that the 1989 Romanian revolution did not bring about a decisive break with state socialism. Instead, there is much continuity with the socialist era and many of Romania's current politicians have roots in the Romanian Communist Party. Thus various respondents spoke of communism as a contemporary force. For example, "The people who still name it that way [Moghioroş] are still communists". Similarly: "We have remained communists: there is a need for two generations to pass before we return to normal". Some respondents said that the older generation is responsible for preserving the socialist place name: "The majority of people who call it that [Moghioros] are older people, they haven't adapted". Similarly: "The majority of people who called it that [Moghioroş] are elderly. The name won't disappear until they all die".

\section{Discussion}

Significantly then, a socialist era toponym - Piaţa Moghioroş - remains in widespread everyday use in Bucharest more than two decades after the end of state socialism. Efforts by political elites to rename the market to de-commemorate Alexandru Moghioroş have not achieved their desired impact. While "toponymic cleansing" (Rose-Redwood, Alderman, and 
Azaryahu 2010) is intended to introduce the values and ideology of the new political order into the mundane spaces of everyday life (Azaryahu 1996, 2009) it has demonstrably not succeeded in this part of Bucharest. Indeed, the continuity in the usage of the socialist-era toponym throws doubt on the effectiveness of renaming as a political strategy to remake the places and spaces of everyday life and points to what Rose-Redwood (2008) terms the 'performative limits' of official naming practices. Moreover, Piaţa Moghioroş is not an isolated example. Respondents were asked if they knew of other streets that had been renamed after 1989 but where the former name remained in use. Seventy-seven people (46 percent) could identify examples and in total thirty-eight different streets were named.

In addition, these findings suggest that placing a new toponym within the urban landscape through its inscription on buildings and street name plates and its incorporation into maps, is not enough to assure that it will be adopted by the public and absorbed into the practices of everyday life. Instead, "old" toponyms can prove to be surprisingly resilient, despite their ideological unacceptability. Although Piaţa Drumul Taberei is clearly labeled as such (as is the adjacent bus stop) this name has not passed into widespread usage. Indeed, 29 percent of those who used the name Piaţa Moghioroş (17 percent of the total sample) were unaware that the market had any other name. The use of another name for the market (Piaţa Sergiu Celibidache) by a minority of respondents throws further doubt on the effectiveness of urban (re-)naming strategies.

Furthermore, not only is Moghioroş the predominant name used for the market but this name now enjoys a broader circulation than during the socialist era. Since in Romanian Piaţa means "square" as well as "market", the name Piaţa Moghioroş is increasingly used to refer to the traffic intersection (officially called Piaţa Sergiu Celibidache) and the surrounding area. This increased use of the former name can be seen in its adoption by local businesses (including those established after 1990) who describe their location as being "at Piaţa Moghioroş" even though this name does not appear on street signs or road maps. For example, a bank near to the market describes itself as the "Moghioroş branch" (Figure 4). A supermarket with branches throughout Bucharest similarly gives details of its "Moghioroş branch" on its website. An area of open land opposite the market which hosts fairs, exhibitions, and an iceskating rink in winter has adopted the name Moghioroş and posters promote events there as being "at Piaţa Moghioroş". Similarly the nearby park, constructed at the same time as the rest of the district and always officially named Parcul Drumul Taberei, is increasingly known 
as Parcul Moghioroş. Consequently posters promoting events give the park's official and unofficial names, reflecting a dual toponymy (Figure 5). Thus, from being the name of the market, Moghioroş is now the name for a broader location within the Drumul Taberei district. The boundaries of this area are not clearly defined, but are set by the everyday use of the term Moghioroş. The mundane activities of local businesses, event organizers and advertisers both reflect and reinforce the way that the name Moghioroş is embedded in local practice and memory, particularly as they promote the use of the old name to new residents and a wider population who may not have first-hand knowledge of that part of the city.

\section{FIGURES 4 AND 5 AFTER HERE SOMEWHERE}

The case of Piaţa Moghioroş is, however, more complex than the persistence of a name from the socialist era. A significant minority (40 percent) of respondents use the new official name for the market. Of this group, all but two were aware that the market was also known as Moghioroş. On the other hand, 67 percent of those people who used the name Piaţa Moghioroş were also aware of the official name of the market. In total, 79.3 percent of respondents were aware that the market went under two names and that parallel toponymies one official, one unofficial - are in circulation. In fact, many users of the market are likely to use the two names interchangeably in their everyday activities and alternate between them depending on who they are talking with and for what purpose (for example, when giving directions or talking about the history of the district). The widespread recognition of the plural names for the market and the choice to use one or the other indicates that Piaţa Drumul Taberei/Moghioroş is a site of toponymic contestation.

Although the majority of people still use the socialist-era name Moghioroş, most people (57 percent) did not associate the name with the person (and even some who do were uncertain about his exact role). The name has become detached from its referent through a process of "semantic displacement" which "disconnects the meaning of the name from the original historical referent without, however, denying the existence of such a referent" (Azaryahu 2009, 62). Thus, for most respondents, the name Moghioroş does not evoke the communist Alexandru Moghioroş. In this sense, Moghioroş is stripped of its ideological significance: it is just a name (and most Romanians would easily identify the word Moghioroş as a surname, 
moreover, one of Hungarian origin). Thus, for most users of the market Moghioroş is now a mundane signifier of a location rather than a commemoration of a socialist leader.

Why, then, has the name Piaţa Moghioroş survived for so long in the post-socialist period? As we have already suggested, one explanation is resistance to an unpopular renaming. Various authors (Azaryahu 1996; Kearns and Berg 2002; Rose-Redwood 2008; Vuolteenaho and Berg 2009; Rose-Redwood, Alderman, and Azaryahu 2010; Alderman and Inwood 2013) have stressed that official efforts to (re)name places can opposed and resisted. Indeed, Bucharest offers its own examples of opposition to an unpopular naming. The best known is Bulevardul 1 Mai (1 May Boulevard) which was renamed Bulevardul Ion Mihalache in 1997. This was intended to commemorate an interwar politician from the National Peasant Party and took place when the mayor of Bucharest belonged to this party (which nationally was part of a coalition government). Yet many Bucharesters resented this renaming arguing that 1 May is an international day of worker's solidarity without specifically socialist associations. In addition, this renaming is often seen as a clumsy effort by the National Peasant Party to foreground its own people (Light 2003). Consequently, the name Bulevardul 1 Mai remains in widespread everyday use (and many of the original name plates remain along the boulevard). Moreover, Bucharest's metro company chose not to rename the 1 Mai underground station which stands at the end of the boulevard.

In this context, the continued use of the name Piața Moghioroș could be interpreted as an act of contestation and resistance among the people of Drumul Taberei. It might indicate an appreciation of the deeds of Alexandru Moghioroş, and a desire to ensure that his reputation is maintained in a context when the socialist era is officially repudiated. Alternatively the continued use of Piaţa Moghioroş may be a purposeful act of defiance among some who lived through the period of Communist Party rule and who are unwilling to see that era erased entirely from the narrative of Romanian history. From this perspective, Piaţa Moghioroş could be considered as a site of "counter-memory" (Foucault 1977). These are places where people have refused to forget and which can rebut the efforts of a dominant elite to (re)define collective memory on their terms (Legg 2005). Thus Piaţa Moghioroş may be the focus of alternative ways of remembering that are grounded in an unwillingness to accept statesponsored efforts to disavow the socialist past in general (and Alexandru Moghioroş in particular). 
We do not deny that efforts to reshape collective memory can be contested; neither do we dispute the importance of sites of counter-memory as places of alternative remembrance (particularly in a post-socialist context). Nevertheless, we find little evidence from our survey to indicate that the continued use of the name Piaţa Moghioroş arises from active opposition to an unpopular renaming. For a start, Alexandru Moghioroş was a second-tier Party activist who died more than four decades ago, so the number of people who can directly remember his contribution to Romanian political life is small. There appears to be no particular affection for him and only nine people argued that his merits as a politician deserved remembrance. The notion of resistance also does not explain why so many young people born after 1989 (who have no direct knowledge of the socialist era and little interest in it) have adopted the name of a socialist politician. Indeed, older people were equally likely to use Piaţa Drumul Taberei while younger people were equally likely to use Piaţa Moghioroş. In short, we found little evidence for deliberate efforts to preserve the name Piaţa Moghioroş in the face of officially-sponsored efforts to erase it from the urban landscape.

Therefore we suggest that notions of resistance do not explain every instance of toponymic contestation. Indeed, Forest, Johnson, and Till $(2004,374)$ argue that the "category of 'counter-memory' as 'resistance' is too simplistic: a range of actors and groups may act in ways not necessarily structured by opposition to state or elite domination". Certainly, in this case other explanations appear more promising. In particular, we suggest that habit and inertia may have more to offer in explaining the persistence of the toponym Piaţa Moghioroș. The issue of habit was raised repeatedly by our respondents. 50 percent of those questioned considered that the persistence of Moghioroş was due to habit, continued use of the original name, or lack of awareness that the name had changed (Table 2). Moreover this situation is not unique: both De Soto (1996) and Rose-Redwood (2008) suggest that habit may account for the persistence of the former names of streets in Berlin and New York.

A considerable body of work exists within social science and philosophy about the nature of habit and the habitual. The work of Pierre Bourdieu is important for highlighting the nonreflective nature of much social practice (Lau 2004) and he notes that habitual behaviour enables people to go about their daily lives without having to consider each and every action they make (Jenkins 2002). Habits are, in turn, a function of the habitus of a particular social class or group (Weiss 2008). This habitus is a system of acquired and internalized dispositions which frames our interaction with the world and the way that we interpret new situations. It 
disposes people to behave in particular ways derived from past experiences, leading to repeated forms of behavior. In this way habits are constitutive of ongoing practices (Swartz 2002). Bourdieu's work is important for understanding social (i.e. collective) behavior among particular groups or classes and his work "encourages researchers to look for ways in which ostensibly individual habits have some collective dimension" (Swartz 2002, 675). Individual variations in the 'working out' of habitus are, however, under-theorized (Lau 2004) and overall Bourdieu's work is less useful for explaining the details of how individuals develop (and maintain) specific habits, particularly those that are not implicated in the formation of group or class identities.

Geographers, too, have a long (if sporadic) history of engagement with habit. For example, Sauer (1941) identified habit as learned attitudes and preferences which are part of a particular group's cultural make up. Writing from a humanistic perspective Seamon (1980, 152) identified habit as a form of "acquired behaviour that has become more or less involuntary" and termed such behavior "time-space routine". He argued that such routines when fused with "body-ballets" (sets of integrated embodied behavior) produced a "placeballet" (a joining of people, space, place, and time) which, in turn, contributed to making the meanings of place. More recently human geographers have renewed their interest in matters of habit and routine. Some have turned to non-representational theory (Thrift 2007) and, in particular, have considered habits in the context of the recent growth of interest in affect. Habits have a clear affective dimension: since they are unreflexive, pre-cognitive, and usually unconscious (see Edensor 2009) they can be one of the ways in which affect is realized (Duff 2010). Some geographers have sought to link habit and affect in the subjective experiences of space and place. For example, Duff (2010) examines the imbrications of habit, affect, and practice in "thick" spaces (cf Casey 2001) that offer intensive and enriching experiences of belonging. Similarly, Edensor $(2012,1114)$ identifies habit and familiarity (and past experience more broadly) as important (but often overlooked) factors which condition the affective and emotional experiences of space.

Another strand of recent work has considered habit in the context of everyday life. This work sees habit not as trivial or constraining but as something dynamic, emergent, and full of transformative potential within strategies for coping with the challenges of the everyday (Binnie et al. 2007; Thrift 2007; Middleton 2011). Embodied habits provide familiarity and consistency to everyday life but also open up tantalizing possibilities, particularly when 
established habits are disrupted (Harrison 2000). They also demonstrate our capability for engaging with new and complex tasks (Highmore 2011). Recent studies of habit have explored the nature of routine mobilities such as commuting (Edensor 2003; Middleton 2011). Other work has explored the role of habit and routine in structuring daily practice such as the use of indoor and outdoor spaces among office workers (Hitchings 2010a, 2010b). Alongside this work on habit and routine is growing attention to rhythm (McCormack 2002; Edensor and Holloway 2008; Edensor 2010). Taking its inspiration from Henri Lefebvre's (2004) Rhythmanalysis, this work explores the role of rhythms in underpinning the practices of everyday life and in (re)constituting place (Edensor 2010). Habits and rhythms are closely related: many habits and routines are underlain and structured by rhythms (although not all habits are rhythmic in nature).

Considered in this context, the continued use of the name Piaţa Moghioroş can be understood as a form of habitual behavior. As a well-practiced unreflexive routine it has become firmly embedded within the everyday practices of the market's users. Moreover, as recent work has recognized (Highmore 2004, 2011) habits are hard to break (even when there is a desire to change them) and people can struggle with (and against) their ingrained habits (Hutchings 2010a). While habits may have a transformative potential and raise the possibilities of reshaping everyday life, this potential has not been realized in the case of the name Piaţa Moghioroș. Overall, while recent work by geographers on habit is important for elucidating the ways in which routine and rhythm structure everyday life (and for highlighting the transformative possibilities of habit) it tells us little about the mechanisms through which habits are formed and, more importantly, how and why they persist so obdurately.

These approaches to understanding habit could be further developed through an engagement with socio-cognitive psychology. Psychologists see habits as a form of learned behavior. They can be defined as "behavioural dispositions to repeat well-practiced actions given recurring circumstances" (Wood, Tam, and Witt 2005, 918). Habits are an important aspect of how people organize everyday life and approximately forty-five percent of all behavior is repeated or habitual (Verplanken and Wood 2006). As actions are repeated on a regular basis an association develops in memory between the action and particular cues so that a form of "automaticity" develops (Wood, Tam, and Witt 2005) in which the behavior is repeated with minimal awareness, attention or conscious control (Wood, Quinn, and Kashy 2002; Neal, Wood, and Quinn 2006; Verplanken and Wood 2006; Highmore 2011). This way of behaving 
is associated with various benefits including cognitive economy and performance efficiency: habitual behavior, quite literally, frees up the brain to do other things, particularly more important or thoughtful forms of cognitive activity (Wood, Quinn, and Kashy 2002; Highmore 2011). Perhaps for this reason, habitual behavior is associated with less intense emotions (Wood, Quinn, and Kashy 2002).

An integral influence on habit formation is the context in which a particular behavior occurs; that is, habits are cued by particular environments (Verplanken and Orbell 2003; Verplanken and Wood 2006). This may be an uncomfortable notion for geographers given the parallels with environmental determinism, but context includes the time of the activity and the people it is performed with, in addition to the environment or setting in which it takes place (Wood, Tam, and Witt 2005; Verplanken and Wood 2006). If the context for a particular habit is stable then that habit is resistant to change. Many studies have established that habits are difficult to break or change, even when there is an intention to do so (Verplanken and Orbell 2003; Holland, Aarts, and Langendam 2005; Wood, Tam, and Witt 2005; Wood and Neal 2007). As Neal, Wood, and Quinn $(2006,201)$ argue, habits "keep us doing what we have always done, despite our best intentions to act otherwise". Indeed, as is well known, some forms of learned behavior (such as riding a bike) are almost impossible to unlearn.

A social-psychological understanding of habit helps explain the persistence of the toponym Piaţa Moghioroș. The practice of using a particular name can be treated as a form of behavior and once the association between a name and a location is learned the use of that name quickly becomes habitual. Like any habit, use of that name will be resistant to change while the context in which the name is being used is stable. It could be argued that the shift from socialism to post-socialism represents a dramatic change of context. As Verdery (1999) argues post-socialist change involves a reordering and redefinition of the most fundamental aspects of everyday life, which might be expected to destabilize even the most deeply ingrained habits. On the other hand, the market itself offers a very stable context within these overall upheavals. It is still a market, it still sells food, it is still a social meeting point, it is still in the same location, and people continue to use it on a regular basis for the same everyday purposes as during the socialist era. Moreover, most of the market's users will continue to use the same routes to get there, which involves walking along familiar pathways, often at the same time of day. A socio-psychological understanding of habit suggests a disposition towards well-practiced behavior in such circumstances (Wood, Tam, and Witt 
2005) as people become habituated to their surroundings (Highmore 2011). Many people may have intended to embrace the new name (and clearly some succeeded in doing so) but habits prove to be enduring despite intentions to change them (Verplanken and Wood 2006). To learn and use the new name (in other words, to change their behavior) required intentionality and motivation, in a context when there was no obvious reward to be gained from adopting the new name. This perspective suggests that only drastic intervention (such as closing the market and reopening it on a new site with a new name) would be successful in erasing the name Piaţa Moghioroş from everyday use.

In any case, soon after the 1989 revolution the question of street names became less important to most inhabitants. During the early 1990s the economic restructuring that followed the dismantling of the hyper-centralized socialist economy resulted in hardship for most Romanians, and the primary concern of Bucharesters was meeting their basic needs for food and heating. Furthermore, given that most of the post-socialist political and economic elite had deep roots in the socialist era, many saw considerable continuity with the previous regime. In this context, the name Piaţa Moghioroș quietly persisted because few people were concerned about the issue and instead continued to use the former name out of habit. The name was already well established in the everyday lives, practices and collective vocabulary of the district. The performative act of using the socialist era name in everyday speech (RoseRedwood 2008) reproduced and re-circulated that name so that it was adopted by a generation born after 1989 because it was the toponym they heard their parents and grandparents using. This accounts for the use of the name Piaţa Moghioroş by the nine year old son of friends of one of the authors. Similarly, new arrivals to the Drumul Taberei district adopt Moghioroș because they hear their neighbors use it, they see it on posters and in shop windows, and they are given directions using it. For example, a group of students from the far north of Romania who lived in the flat above one of the authors in 2004 swiftly adopted the socialist-era name when they moved to the capital and were entirely unaware that the market had any other name.

Overall, then, notions of habit within everyday practices - rather than purposeful acts of resistance and contestation - seem a more convincing explanation for the persistence of the name Piaţa Moghioroş. However, resistance and habit are not necessarily mutually exclusive categories. For example, Edensor $(2009,544)$ speaks of the "blurred boundaries between purposive and unreflexive action". In this context we suggest that everyday habits, while 
given little conscious attention, may or may not be apolitical. Habits can represent embodied challenges to the established order, even if this was not deliberately or consciously intended. There are parallels here with De Certeau's walkers in the city who, through their unreflexive everyday practices (or tactics), quietly challenge and subvert an unseen authority (even if sometimes they are not aware of doing so).

Therefore, while habits may appear to be mundane and unthinking forms of behavior, we suggest that they may also be quietly disruptive performative acts. The use of a nowrepudiated name such as Piaţa Moghioroş, even if in an unconscious and habitual way, is a rebuke to the state's monopoly and control of the process of naming urban space. It constitutes a form of counter-performance that denies the legitimacy of the act of elite renaming and the authority of the namer (cf Rose-Redwood 2008). Thus, the use of the name Piaţa Moghioroş - even if unreflexively - subverts elite-sponsored efforts to produce an 'appropriate' post-socialist public landscape in Bucharest. Moreover, habits are formed in a particular political and social context. Their expression within everyday lives is a performative enactment of that context. While the use of the name Piaţa Moghioroş may be unthinking it still evokes a form of political order - state socialism - that is currently rejected. The very utterance of the name can be considered as a small (and unwilled) challenge to the new political order.

In addition, the habitual use of socialist-era names may be an unconscious reaction to the upheaval and dislocation of the early post-socialist period. In conditions when the entire context of everyday life was turned upside Bucharesters needed to devise coping strategies. A commonplace way of dealing with such situations is to try to ground senses of identity through holding on to objects, ideas or memories that offer familiarity, stability and reassurance. The continued (if unreflexive) use of familiar place names can be interpreted as a part of this strategy. In this sense, place names are associated with (and rooted in) broader senses of belonging and attachment to place (Alderman and Inwood 2013). The habitual use of socialist-era toponyms expresses both a renewed value attached to the socialist past, and an ambivalence towards the prevailing orthodoxies of neoliberalism and Europeanization that are dominant within post-socialist Romania. Overall, then, everyday habits can embody a broad range of individual dispositions towards the exit from socialism and the embrace of an uncertain future. As such, they illustrate what Moran (2005) terms the unacknowledged cultural politics of the (seemingly) banal. 


\section{Conclusion}

Cultural and political geographers have written extensively in recent years about the relationships between urban landscapes, political order, and public memory. The reification of authorized narratives of memory within the urban arena is well recognized. The nature of the public commemorative landscape is, however, liable to transformation at critical moments of radical or revolutionary political change (Forest and Johnson 2002). In this context, a growing body of work has explored this issue in post-socialist Central and Eastern Europe. The collapse of state socialist regimes was accompanied by efforts to erase the public symbols of socialism and to reconfigure the urban landscape to express new narratives of national history, identity, and memory. This process is frequently represented as being clean, decisive, and final. However, as we have explored in this article, the power of political elites to reshape urban space and public memory is not absolute. Instead urban residents can respond to elite projects to reconfigure urban space and public memory in a variety of ways that were not anticipated or intended (cf Forest, Johnson, and Till 2004).

This article has examined this issue with reference to one toponym, a market originally named after Alexandru Moghioroş. Although Moghioroş is long dead his name lives on. It was originally introduced into the daily practice and language of the Drumul Taberei district through naming a boulevard and market in his honor. Efforts after 1989 to de-commemorate Moghioroș through renaming these places have achieved only limited success. Instead, Moghioroş's name remains in widespread daily use in Drumul Taberei even if the majority of people have little idea who he was. Moghioroș is an absent presence; a ghost of the socialist era who continues to quietly haunt the post-socialist city (cf. Edensor 2005).

This study raises questions about the effectiveness of strategies to rename urban places following a radical political change. Official efforts to eradicate the toponymy of socialism (and the authorized memory expressed in that toponymy) may be less effective than is sometimes appreciated. Czepczyński (2009, 109) talks of the "leftover landscapes" of socialism and certainly many such landscape features created by socialist regimes have quietly endured, unscathed, throughout the post-socialist era (Light and Young 2010, 2011). In a similar way we can talk about "leftover" or "residual" toponymies of state-socialism: urban place names from the socialist era that have survived (both in everyday practice but 
sometimes also in material form such as street name plates) into the third decade of postsocialism. In this article we have focused on Piaţa Moghioroș but it is one of many examples.

How, then, can we explain the persistence of the toponym Piaţa Moghioroş? Or, in broader terms, why do particular place names persist even when they have been purposefully replaced by another name considered more appropriate? The critical toponymies literature emphasizes that top-down and elite-sponsored processes of naming and renaming places can be contested and resisted within the practices of everyday life. Thus, "old" place names can become sites of alternative or counter-memory. Whilst acknowledging the importance of resistance we argue that such a focus has its limitations and does not help explain every instance of the continuity of older street names. Certainly we found little evidence to suggest that practices of contestation and resistance explain the persistence of Piaţa Moghioroș. Instead, in a context where geographers are increasingly engaging with habit we have argued that a focus on seemingly banal, habitual practices has much to offer in understanding why former toponyms persist within everyday practice. In particular, we have employed a perspective from sociocognitive psychology to help understand why now-discredited toponyms persist in everyday use. This perspective stresses that habits are a form of learned behavior that are stable and resistant to change if the contexts in which they are enacted also remain stable. This can explain why the adoption of a particular name for a particular place persists while the meanings of that place (somewhere to purchase food) similarly remain unchanged. Thus, many people in Drumul Taberei have not adopted the new name for Piaţa Moghioroș because the former name is so firmly embedded in their daily practices, habits, and routines.

Recent articles have set out a promising set of future directions for critical place name studies (Rose-Redwood, Alderman, and Azaryahu 2010; Rose-Redwood and Alderman 2011; RoseRedwood 2011). In particular they call for more attention to the commodification of place naming rights, matters of scale, and seemingly banal naming practices. We would fully endorse these agendas but would also call for more analysis of the reception of place names by those whose lives are most directly affected by them. Much of the work within the critical toponymy perspective has focused on officially-sponsored practices of (re)naming places but has neglected everyday responses to such practices (and those studies that have considered this issue usually do so through the lens of resistance). We suggest there is a need for further investigation into how place names (and place name changes) are embraced, negotiated or rejected within the everyday lives of the inhabitants of the city. To do this requires talking to 
people in detail about the significance of place names for them which, in turn, requires an openness in terms of methodologies and conceptual frameworks. This study has illustrated how a mixed-method approach can be used to explore popular responses to urban place names and we have also demonstrated how both representational and non-representational perspectives can be employed for interpreting a particular renaming. By developing a richer and more nuanced understanding of the ways in which people respond to place names in their everyday lives we can better appreciate why and how naming works (or does not work) and, more broadly, how relationships with urban landscapes contribute to the construction of collective memory.

\section{Acknowledgements}

We would like to thank Daniela Dumbrăveanu who first drew our attention to Piaţa Moghioroş, and Cristian Ciobanu and Anca Tudoricu for their help in the collection of data. We would also like to thank Lorna Bourke, Tim Edensor, Julian Holloway and David Merryweather for their help in shaping the argument of this article. Thanks also to three anonymous reviewers for insightful comments on an earlier draft. 


\section{References}

Alderman, D. 2002. Street names as memorial arenas: the reputational politics of commemorating Martin Luther King, Jr. in a Georgia county. Historical Geography 30: 99120.

--- and J. Inwood. 2013. Street naming and the politics of belonging: spatial injustices in the toponymic commemoration of Martin Luther King Jr. Social and Cultural Geography 14(4): 211-33.

Azaryahu, M. 1996. The power of commemorative street names. Environment and Planning D: Society and Space 14(3): 311-30.

- - - 1997. German reunification and the politics of street names: the case of East Berlin. Political Geography 16(6): 479-93.

- - -. 2009. Naming the past: the significance of commemorative street names. In Critical Toponymies: The Contested Politics of Place Naming, ed. L. Berg and J. Vuolteenaho, 53-67. Farnham: Ashgate.

- - 2011. The critical turn and beyond: the case of commemorative street naming. $A C M E$ : An International E-Journal for Critical Geographies 10(1): 28-33.

- - -. 2012. 'Rabin's road': the politics of toponymic commemoration of Yitzak Rabin in Israel. Political Geography 31(2): 73-82.

Berg, L., and J. Vuolteenaho. (eds.) 2009. Critical Toponymies: The Contested Politics of Place Naming. Farnham: Ashgate.

Binnie, J., J. Holloway, S. Millington, and C. Young. 2007. Mundane geographies: alienation, potentialities, and practice. Environment and Planning A 39(3): 515-20.

Boia, L. 2001. History and Myth in Romanian Consciousness. Budapest: Central European University Press.

Casey, E. 2001. Between geography and philosophy: what does it mean to be in the placeworld? Annals of the Association of American Geographers 91(4): 683-93.

Czepczyński, M. 2009. Cultural Landscapes of Post-Socialist Cities: Representations of Powers and Needs. Aldershot: Ashgate.

De Certeau, M. 1984. The Practice of Everyday Life. Berkeley: University of California Press.

De Soto, H. G. 1996. (Re)Inventing Berlin: Dialectics of power, symbols and pasts, 19901995. City and Society 8(1): 29-49.

Duff, C. 2010. On the role of affect and practice in the production of place. Environment and Planning D: Society and Space 28(5): 881-95.

Edensor, T. 2003. Defamiliarizing the mundane roadscape. Space and Culture 6(2): 151-68. 
- -. 2005. The ghosts of industrial ruins: ordering and disordering memory in excessive space. Environment and Planning D: Society and Space 23(6): 829-49.

- - -. 2009. Tourism and performance. In: The Sage Handbook of Tourism Studies, ed. T. Jamal and M. Robinson, 543-57. London: Sage.

- - -. 2010. Introduction: thinking about rhythm and space. In Geographies of Rhythm: Nature, Place, Mobilities and Bodies, ed. T. Edensor, 1-18. Aldershot: Ashgate.

- -. 2012. Illuminated atmospheres: anticipating and reproducing the flow of affective experience in Blackpool. Environment and Planning D: Society and Space 30(6): 1103-22.

- --, and J. Holloway. 2008. Rhythmanalysing the coach tour: the Ring of Kerry, Ireland. Transactions of the Institute of British Geographers 33(4): 483-501.

Ekman, J., and J. Linde. 2005. Communist nostalgia and the consolidation of democracy in Central and Eastern Europe. Journal of Communist Studies and Transition Politics 21(3): 354-74.

Forest, B. and J. Johnson. 2002. Unravelling the threads of history: Soviet-era monuments and post-Soviet national identity in Moscow. Annals of the Association of American Geographers 92(3): 524-47.

Forest, B., J. Johnson, and K. Till. 2004. Post-totalitarian national identity: public memory in Germany and Russia. Social and Cultural Geography 5(3): 357-80.

Foucault, M. 1977. Language, Counter-memory, Practice. Ithaca: Cornell University Press.

Harrison, P. 2000. Making sense: embodiment and the sensibilities of the everyday.

Environment and Planning D: Society and Space 18(4): 497-517.

Highmore, B. 2004. Homework: routine, social aesthetics and the ambiguity of everyday life. Cultural Studies 18(2/3): 306-27.

- -. 2011. Ordinary Lives: Studies in the Everyday. London: Routledge.

Hitchings, R. 2010a. Seasonal climate change and the indoor city worker. Transactions of the Institute of British Geographers 35(2): 292-98.

- - - 2010b. Urban greenspace from the inside out: an argument for the approach and a study with city workers. Geoforum 41: 855-64.

Holland, R. W., H. Aarts, and D. Langendam. 2005. Breaking and creating habits on the working floor: a field-experiment on the power of implementation intentions. Journal of Experimental Social Psychology 42(6): 776-83.

Jenkins, R. 2002. Pierre Bourdieu (Revised Edition). London: Routledge. 
Kearns, R. A. 2005. Knowing seeing? Undertaking observational research. In Qualitative Research Methods in Human Geography (Second Edition). ed. I. Hay, 192-206. Oxford: Oxford University Press.

Kearns, R. A., and L. D. Berg. 2002. Proclaiming place: towards a geography of place name pronunciation. Social and Cultural Geography 3(3): 283-302.

Lau, R.W.K. 2004. Habitus and the practical logic of practice: An interpretation, Sociology 38(2): 369-387.

Legg, S. 2005. Sites of counter-memory: The refusal to forget and the nationalist struggle in Colonial Delhi. Historical Geography 33: 180-201.

Lefebvre, H. 2004. Rhythmanalysis: space, time and everyday life. London: Continuum.

Light, D. 2003. Political change and official public landscapes: renaming streets in Bucharest after 1989. Romanian Journal of Society and Politics 3(1): 106-31.

- - - 2004. Street names in Bucharest 1990-1997: exploring the modern historical geographies of post-socialist change. Journal of Historical Geography 30(1): 154-72.

- --, and C. Young. 2010. Reconfiguring socialist urban landscapes: the 'left-over' spaces of state-socialism in Bucharest. Human Geographies: Journal of Studies and Research in Human Geography 4(1): 5-16.

- - -, and C. Young. 2011. Socialist statuary as post-socialist hybrids: following the statues of Dr Petru Groza in Romania. Journal of Historical Geography 37(4): 493-501.

McCormack, D. P. 2002. A paper with an interest in rhythm. Geoforum 33: 469-85.

Middleton, J. 2011. "I'm on autopilot, I just follow the route": exploring the habits, routines, and decision-making practices of everyday urban mobilities. Environment and Planning $A$ 43(12): 2857-77.

Moran, J. 2005. Reading the everyday. London: Routledge.

Neal, D. T., W. Wood, and J. M. Quinn. 2006. Habits - A repeat performance. Current Directions in Psychological Science 14(4): 198-202.

Rose-Redwood, R. S. 2008. "Sixth avenue is now a memory": regimes of spatial inscription and the performative limits of the official city-text. Political Geography 27: 875-94.

- - -. 2011. Rethinking the agenda of political toponymy. ACME: An International E-Journal for Critical Geographies 10(1): 34-41.

- - -, and D. Alderman. 2011. Critical interventions in political toponymy. ACME: $A n$ International E-Journal for Critical Geographies 10(1): 1-6. 
- - -, D. Alderman, and M. Azaryahu. 2010. Geographies of toponymic inscription: new directions in critical place-name studies. Progress in Human Geography 34(4): 453-70.

Sauer, C. O. 1941. Forward to historical geography. Annals of the Association of American Geographers 31(1): 1-24.

Scott, S. 2009. Making sense of everyday life. Cambridge: Polity Press.

Seamon, D. 1980. Body-subject, time-space routines, and place-ballets. In The Human Experience of Space and Place, ed. A. Buttimer and D. Seamon, 148-65. London: Croom Helm.

Swartz, D. L. 2002. The sociology of habit: The perspective of Pierre Bourdieu. Occupational Therapy Journal of Research 22(1): 615-95.

Thrift, N. 2007. Non-Representational Theory: Space, Politics, Affect. London: Routledge.

Todorova, M., and Z. Gille. (eds.) 2012. Post-Communist Nostalgia. Oxford: Bergahn Books.

Verdery, K. 1999. The Political Lives of Dead Bodies: Reburial and Postsocialist Change. New York: Columbia University Press.

Verplanken, B., and S. Orbell. 2003. Reflections on past behaviour: a self-report index of habit strength. Journal of Applied Social Psychology 33(6): 1313-30.

- - -, and W. Wood. 2006. Interventions to break and create consumer habits. Journal of Public Policy and Marketing 25(1): 90-103.

Vuolteenaho, J., and L. Berg. 2009. Towards critical toponymies. In Critical Toponymies: The Contested Politics of Place Naming, ed. L. Berg and J. Vuolteenaho, 1-18. Farnham: Ashgate.

Weiss, G. 2008. Can an old dog learn new tricks? Habitual horizons in James, Bourdieu, and Merleau-Ponty. In Intertwinings: Interdisciplinary encounters with Merleau-Ponty, ed. G. Weiss, 223-240. Albany: State University of New York Press.

Wood, W., and D. T. Neal. 2007. A new look at habits and the habit-goal interface. Psychological Review 114 (4): 843-63.

- - -, J. M. Quinn, and D. A. Kashy. 2002. Habits in everyday life: thought, emotion and action. Journal of Personality and Social Psychology 83(6): 1281-97.

- - -, L. Tam, and M. G. Witt. 2005. Changing circumstances, disrupting habits. Journal of Personality and Social Psychology 88(6): 918-33.

Yeoh, B. 1992. Street names in colonial Singapore. Geographical Review 82(3): 313-22. 
Correspondence: Division of Geography and Environmental Management, School of Science and the Environment, Manchester Metropolitan University, John Dalton Building, Chester Street, Manchester, M1 5GD, UK, email d.light@mmu.ac.uk (Light), c.young@mmu.ac.uk (Young). 


\section{Figure captions:}

Figure 1. Location map of Piaţa Drumul Taberei/Piaţa Moghioros

Figure 2. General view of Piaţa Drumul Taberei at the Piaţa Sergiu Celibidache intersection

Figure 3. New signage on the market indicating its post-socialist name.

Figure 4. A bank advertises itself as the Moghioroș branch.

Figure 5. A poster advertising an event in Parcul Drumul Taberei which also uses the original name (Moghioroș). 